\title{
RESEARCH PAPER \\ POSSIBLE ABSTRACTION SITES ALONG OSUN RIVER LOWER COURSE IN OGUN AND LAGOS STATES, NIGERIA FOR SUSTAINABLE SUPPLY OF POTABLE WATER
}

\author{
J. A. Awomeso 1 , A. M. Taiwo ${ }^{2}$, O. A. Morawo ${ }^{3}$ and J. O. Moyosore ${ }^{1}$ \\ ${ }^{l}$ Department of Water Resources and Agro-meteorology, University of Agriculture, Abeokuta, \\ Nigeria. \\ ${ }^{2}$ Division of Environmental Health Risk Management, University of Birmingham, UK \\ ${ }^{3}$ Osot Associates Consulting Engineers, Ibadan, Nigeria \\ Correspondent e-mail: taiwoademat2003@yahoo.com, julius_awomeso@yahoo.com,
}

\begin{abstract}
:
Water scarcity remains a major challenge in all the developing nations of the world; not because of paucity of surface water (rivers and streams) that could be abstracted for treatment, but, finding a suitable and sustainable abstraction site. The main objective of this research is to identify good locations, where water treatment plant could be sited along Osun River in Ogun and Lagos State for sustainable production of potable water. To achieve this, water quality of Osun River upstream Lekki lagoon was investigated at three sampling stations; Ogbere, Igbonla and Lekki. Water parameters such as physical (temperature, solids, turbidity) chemicals (pH, electrical conductivity (EC), dissolved oxygen (DO), chemical oxygen demand (COD), nitrate, phosphate, chloride and sulphate, alkalinity, potassium, lead, chromium, iron) and bacteriological (feacal coliform) were determined using standard procedures. The results revealed that Ogbere and Igbonla stations are better locations where water could be abstracted from Osun River than Lekki stations due to low measured parameters (indicators of water pollution), which were within World Health Organization (WHO) acceptable limits. The findings also showed that while raw water abstraction from Osun River at Ogbere and Igbonla stations would require a conventional treatment, raw water from the Lekki lagoon (station) would require special treatment especially desalination due to high chloride and EC contents with expected cost implication.
\end{abstract}

Keywords: potable water, sampling stations, abstraction, Osun River, water quality parameter

\section{INTRODUCTION}

Surface water abstraction serves different purposes. Water is abstracted for public water supply, electricity generation, agriculture, fish farming, industrial and other purposes (DEFRA, 2011). In developed and developing nations all over the world, $50 \%$ of all abstracted water is channeled towards electricity usage while $75 \%$ accounts for industrial purposes (Turnpenny and Coughlan, 2003). In
England and Wales, a range of 33.1 - 41.6 thousand megamillion per day amount of water has been abstracted between 1999 and 2008. Each Briton therefore, has access to $860 \mathrm{~L}$ water per day from abstracted water (DEFRA, 2011). In a nation like Nigeria, water scarcity is a major problem like in any other developing countries (Taiwo, 2011). For instance, Lagos Water Corporation provides potable water for about 35 percent of the population of Lagos State. The 
remaining 65 percent obtains their water supply from various sources including privately owned dug wells and boreholes for their daily survival. The total installed production capacity of all water treatment facilities belonging to Lagos Water Corporation (LWC) is 680 million litters per day (MLD) out of which 150 MLD (22 percent) is based on groundwater. The groundwater based waterworks are categorized into Mini Water Works (10.0 to 13.5 MLD) and Micro Water Works (below 4.5 MLD). There are three major waterworks and they are based on surface water. These are Iju Water Works with a designed capacity of 216 MLD, Adiyan Water Works with capacity of 240 MLD and Isasi Water Works (designed capacity of 18 MLD).

Although, groundwater aquifers in Lagos are yielding well, they are at high risks of saline water intrusions from the Atlantic Ocean.

Therefore, groundwater potential as an alternative consideration for meeting new water schemes is not of economic value for abstraction. This is the reason why surface water is now being considered as an alternative source to boost the present urban water supply in Lagos and Ogun state. To increase the drinking water production by LWC, more large scheme (s) will be required to join the existing major, mini and micro schemes. The major river in Lagos state where raw fresh water could be abstracted and treated for drinking water production for masses is Osun River. The situation of water scarcity is also being experienced in Ogun state and other states of the Federation. For instance, Ogun State Water Corporation had witnessed a decline in water production in the past four years (Orebiyi et al., 2010). Potable water scarcity is a peculiar problem in $\mathrm{Ni}$ geria at large (Gbadebo et al., 2010; Taiwo et al., 2010). It is a time for the government at the center to wade into this matter, so that the goal of the World Health Organization (WHO) in relation to access to adequate drinking water supply could be achieved (WHO, 2006; Taiwo et al..2 2010). The question now is at what location of Osun River should a water treatment plant be sited for water abstraction and treatment in a sustainable manner? The abstraction point, apart from other engineering consideration is determined by the water quality parameters. This is the major focus of this paper, by examining the water quality of the Osun River at three major stations along the catchments area of the River. These locations were purposefully identified because of the existing infrastructure like electricity and accessible road network. Nevertheless, where ever the water treatment plant is located along the River, potable water could be distributed to other parts of the country most especially Lagos with pipes.

\section{Hydraulic Properties of Aquifers in Study Area}

Within the Lagos state catchment of the Osun River, four (4) aquifers were identified (Longe et al., 1987). The upper aquifer extends roughly to $12 \mathrm{~m}$ below the ground, while the second aquifer is encountered between $20 \mathrm{~m}$ and $70 \mathrm{~m}$ below sea level. The third aquifer is found at depths $130 \mathrm{~m}$ to $160 \mathrm{~m}$ below sea level, dipping towards the coast where it ranges from $170 \mathrm{~m}$ to $210 \mathrm{~m}$ below sea level, with a thickness ranging from $15 \mathrm{~m}$ to $30 \mathrm{~m}$. The fourth aquifer can be found at approximately $450 \mathrm{~m}$ below sea level. It is separated from the third aquifer by a rather thick layer of shale of the Ewekoro formation. The water-bearing strata consist of sands, gravels or admixtures of the two. There are textural variations from fine through medium to coarse sands and they are poorly to well graded. When near the surface, the sand deposits are generally loose but become moderately dense with depth and occasionally with clay inter-beds. All the areas are made up of multilayer aquifer systems but can be reduced to three major ones. A subsurface sequence delineation and saline mapping of Lagos State has been studied by Olorunfemi (2004). The borehole resistivity $\operatorname{logs}$ delineate saline water at shallow with fresh/saline water interface at depths ranging from 8 - 15m (Olorunfemi, 
2004). Confined saline water was delineated at deep levels. Delineated saline water zone extends from about $2.5 \mathrm{~km}$ from the coast area to $12.5 \mathrm{~km}$ within Lagos metropolitan where excessive groundwater abstraction has led to the up-coning of the basal saline water.

\section{METHODOLOGY \\ The Study Area}

Osun River Basin is located in an area whose boundaries are approximately latitudes $8^{\circ} 20^{\prime} \mathrm{N}$ and longitudes $5^{\circ} 10^{\prime} \mathrm{E}$ and occupies approximately 9,900 square kilometer of land area. The greater part of Osun River Basin is located in Oyo and Ogun states with less than 7 percent of the total area located in Kwara and Lagos states (OORBDA, 1982). Osun River takes its source from Oshogbo, Osun state and flows through Ogbere (Ijebu-Ode/Benin Road), Ogun state, Igbonla and empties its content into Lekki Lagoon in Epe (Lagos state). The main socioeconomic activities of people living around the Osun River are farming and fishing with little population into sand dredging (Adeleke et al., 2011). Adeleke et al. (2010) observed that about 20, 000 people live around the Ogun state axis of Osun River water course in rain forest ecological zone. These people use the water from the river for domestic purpose, fishing, recreation and washing. Sand-dredging activities also take place along the River water course in these areas.

\section{Sampling and Analysis}

Water samples were collected randomly from twenty sampling locations in three communities (five sampling points in Ogbere, eight in Igbonla, and seven in Lekki) along Osun River with 2.5 litres plastic kegs, which have been thoroughly washed and rinsed many times with deionised distilled water. At collection points, sampling kegs were rinsed with the raw water samples. Sampling was carried out between April and August, 2009.

\section{Analytical Methods}

Physical, chemical and bacteriological analyses of water samples were carried out using stan- dard procedures. Colour, turbidity, total suspended solid (TSS) were determined colorimetrically with spectrometer (APHA, 1998); temperature, $\mathrm{pH}$, conductivity and total dissolved solids (TDS) were determined using mercury in glass thermometer, $\mathrm{pH}$ meter and electrical conductivity (EC) and TDS meter (Combo Hi 98130, Hanna, USA), respectively. Total solids (TS) were obtained by summation of TDS and TSS values. Dissolved oxygen (DO) was determined by Winkler titration method described by Ademoroti (1996), alkalinity and chloride by titrimetric method (APHA, 1998), chemical oxygen demand (COD) by colorimetric reflux method (Ademoroti, 1996). Metals were analyzed by Atomic Absorption Spectrophotometry (AAS, Perkin Elmer 330) after the water samples had been pre-concentrated by heating $100 \mathrm{~mL}$ acidified water samples on a hot plate for 30 minutes (Jaji et al., 2007). However; potassium analysis was done by flame photometric method. Analysis of feacal coliform was carried out using Total Viable Cell Count (TVCC) method described by Ademoroti (1996). Results were subjected to statistical analysis of variance (ANOVA), Duncan Multiple Range Test using SPSS for windows software version 19.0.

\section{RESULTS}

The results of analyzed parameters of the water samples at Ogbere, Igbonla and Lekki stations are presented in Table 1. Range of physicochemical parameters observed at the three sampling points are: temperature $\left(26-32{ }^{\circ} \mathrm{C}\right), \mathrm{pH}$ (7.0 - 8.0), EC (0 - $62 \mathrm{MS} / \mathrm{cm})$, turbidity (0 - 36 NTU), alkalinity (50 -140 mg/L), DO (2.0 - 4.0 $\mathrm{mg} / \mathrm{L})$, COD (1.0-7.0 mg/L), TDS (291$50398 \mathrm{mg} / \mathrm{L})$, TSS (0 - $30 \mathrm{mg} / \mathrm{L})$, nitrate $(2.0$ $11 \mathrm{mg} / \mathrm{L})$, phosphate $(1.0$ - $2.0 \mathrm{mg} / \mathrm{L}), \mathrm{Fe}(0.22$ $-0.77 \mathrm{mg} / \mathrm{L}), \mathrm{Cr}$ (ND-0.001), Zn (0 - $0.24 \mathrm{mg} /$ $\mathrm{L}), \mathrm{K}(0-1.0 \mathrm{mg} / \mathrm{L}), \mathrm{Pb}(0-1.0 \mathrm{mg} / \mathrm{L})$ and faecal coliform (24 - $242 \mathrm{cfu} / 100 \mathrm{~mL})$. Hg was not detected in all the water samples. Figures 1 and 2 show the values of total solids, chloride and sulphate. High concentrations of these parameters were found to be high in Lekki sampling station. Water $\mathrm{pH}$ at the three sampling 


\section{Awomeso et al.}

sites was slightly alkaline with little or insignificant variations. Most of the observed parameters were significantly $(\mathrm{p}<0.05)$ different from one sampling location especially at Lekki sampling station except $\mathrm{pH}$, DO, nitrate, phosphate, $\mathrm{Zn}$ and potassium. Results trend also depicted a significantly higher $(\mathrm{p}<0.05)$ values of TDS, TS, EC, alkalinity, chloride, COD, sulphate, chromium and faecal coliform at Lekki site relative to the other two sites. Water quality values are compared with international and local standards shown in Table 2.

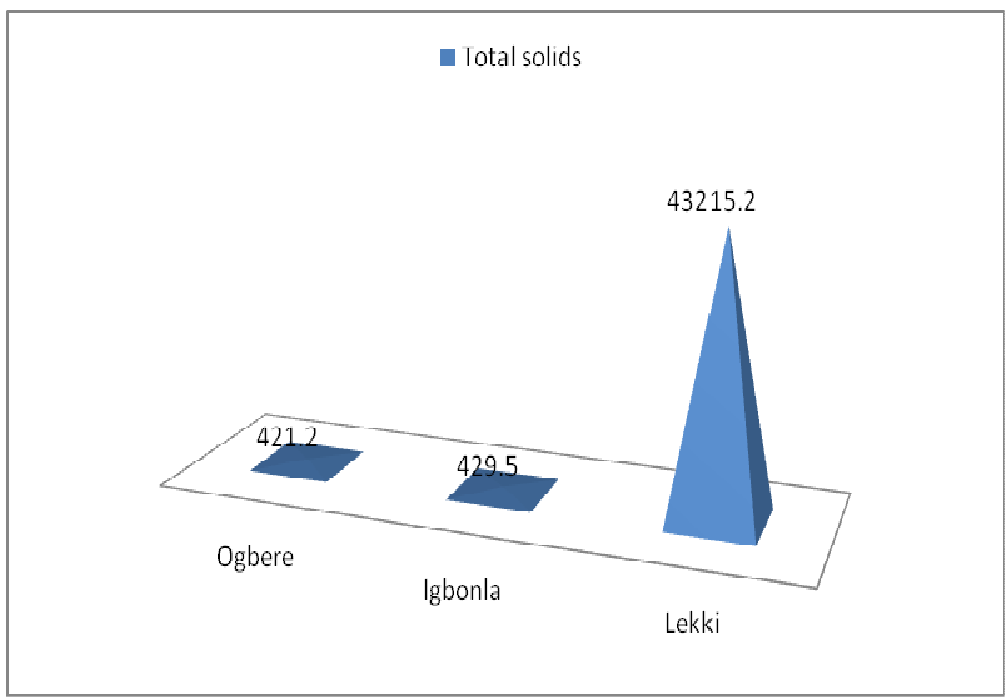

Fig. 1: Comparison of the average values of total solids at the sampling stations in $\mathrm{mg} / \mathrm{L}$

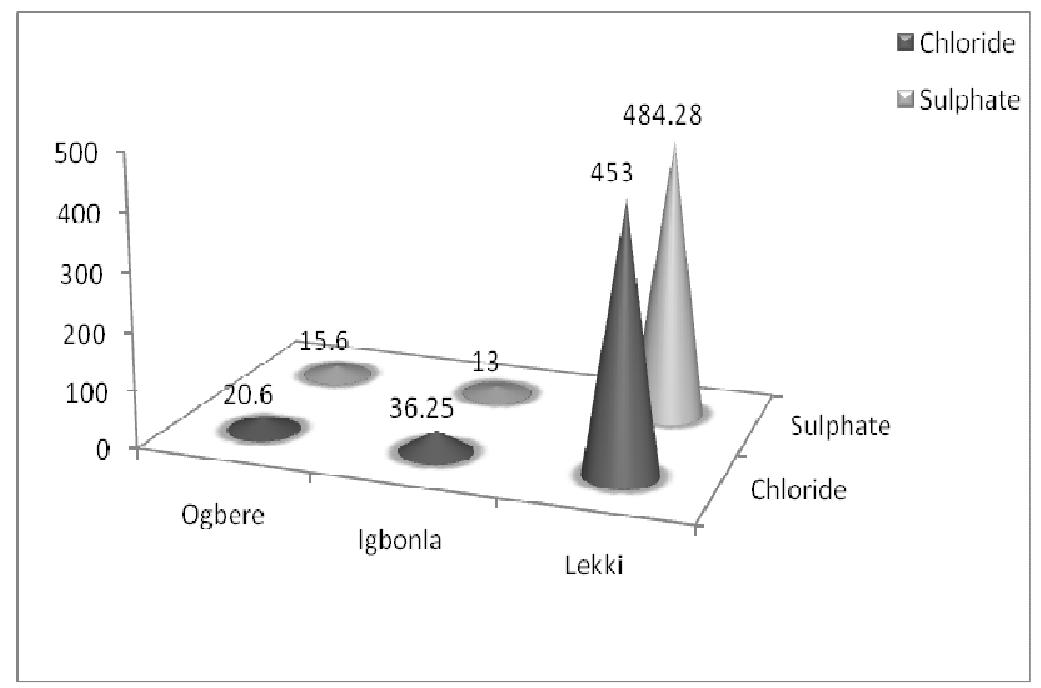

Fig. 2: Average chloride and sulphate concentrations of water sample at the sampling stations in $\mathrm{mg} / \mathrm{L}$

Journal of Science and Technology 다 KNUST December 2011 


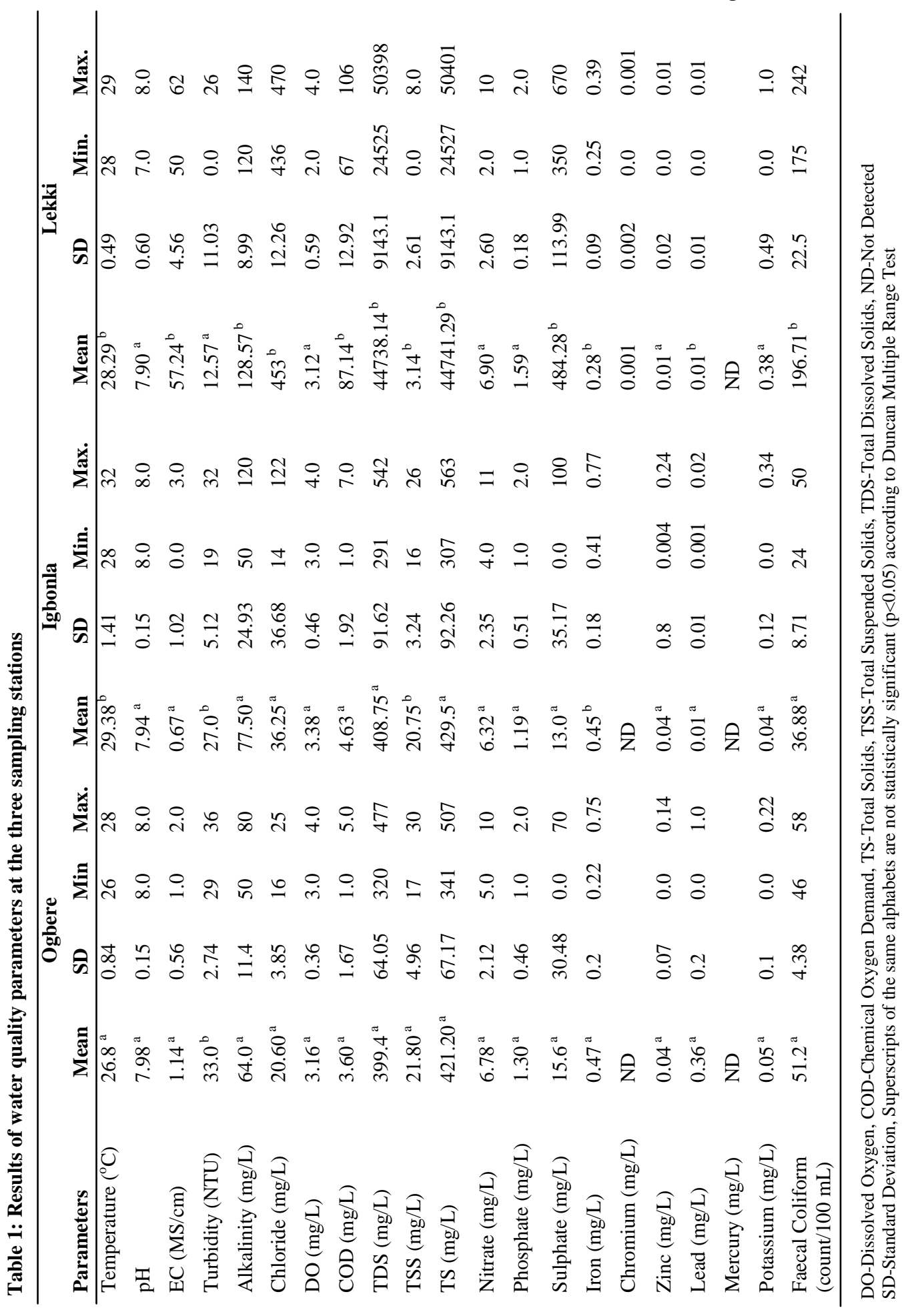


Table 2: Water quality permissible standards

\begin{tabular}{|c|c|c|}
\hline Parameters & WHO (2008) & $\begin{array}{l}\text { FEPA } \\
(1991)\end{array}$ \\
\hline Temperature $\left({ }^{\circ} \mathrm{C}\right)$ & & $<40$ \\
\hline $\mathrm{pH}$ & $6.5-8.5$ & $6.0-9.0$ \\
\hline Turbidity ( NTU) & $<5.0$ & \\
\hline Chloride $\left(\mathrm{mg} \mathrm{L}^{-1}\right)$ & $200-300 *$ & 600 \\
\hline $\operatorname{TDS}\left(\mathrm{mg} \mathrm{L}^{-1}\right)$ & $<600 *$ & 2000 \\
\hline $\mathrm{TSS}\left(\mathrm{mg} \mathrm{L}^{-1}\right)$ & & 30 \\
\hline Nitrate $\left(\mathrm{mg} \mathrm{L}^{-1}\right)$ & 50 & 20 \\
\hline Sulphate $\left(\mathrm{mg} \mathrm{L}^{-1}\right)$ & $<250^{*}$ & 500 \\
\hline Sodium (mg L $\left.{ }^{-1}\right)$ & 200 & \\
\hline Iron $\left(\mathrm{mg} \mathrm{L}^{-1}\right)$ & $0.30 *$ & 20 \\
\hline $\mathrm{Pb}\left(\mathrm{mg} \mathrm{L}^{-1}\right)$ & 0.01 & $<1.0$ \\
\hline $\mathrm{Hg}\left(\mathrm{mg} \mathrm{L}^{-1}\right)$ & 0.06 & 0.05 \\
\hline Color TCU & 15.0 & \\
\hline $\operatorname{Zinc}\left(\mathrm{mg} \mathrm{L}^{-1}\right)$ & $3-5^{*}$ & $<1.0$ \\
\hline $\mathrm{Cr}\left(\mathrm{mg} \mathrm{L}^{-1}\right)$ & 0.05 & $<1.0$ \\
\hline Coliform & $0\left(\right.$ count $\left./ 100 \mathrm{~m} \mathrm{~L}^{-1}\right)$ & $400 \mathrm{MPN}$ \\
\hline $\mathrm{DO}\left(\mathrm{mg} \mathrm{L}^{-1}\right)$ & & 5.0 \\
\hline
\end{tabular}

*Non health-based guidelines

\section{DISCUSSION}

Water parameters such as temperature, $\mathrm{pH}$, alkalinity, nitrate, $\mathrm{Cr}$ and $\mathrm{Zn}$ have their values fall within the safe limits of WHO (2008) and FEPA (1991) for drinking water. The values of phosphate were relatively high at all the sampling locations. Phosphate value above 0.01 $\mathrm{mg} / \mathrm{L}$ has been reported to increase microbial growth in water (Miettinen et al., 1997). In unpolluted water, total phosphorus is in the range $0.01-0.05 \mathrm{mg} / \mathrm{L}$ (Miettinen et al., 1997). Phosphate values above $0.2 \mathrm{mg} / \mathrm{L}$ in rivers, and $0.085 \mathrm{mg} / \mathrm{L}$ in lakes can cause undesirable environmental problems in freshwater (www.environment-agency.gov.uk).

Olajire and Imeokparia (2001) have reported similar high concentration of phosphate (1.48 $\mathrm{mg} / \mathrm{L}$ ) at the upper course of Osun River. High concentration of phosphate in Ogun River has also been observed by Jaji et al. (2007). The presence of high phosphate concentration at these stations indicates pollutions from domestic, municipal and agricultural wastes (Correll, 1998; Jaji et al., 2007). Ecological effect of phosphate is eutrophication, and this could pose great threat to water treatment plant. High concentration of phosphate could also have cost implication of the water abstraction and treatment. Another significant effect of high phosphate in water is oxygen reduction (D'Amelio, 2007), this may have resulted in the generally low DO observed at all the sites. Low DO in rivers and streams could lead to deaths of aquatic organisms (Einum et al., 2002).

Turbidity is an important operational parameter in process control of water treatment. High turbidity could protect microorganisms from disinfection and could stimulate bacterial growth in drinking water (WHO, 2008). However, turbidity could be easily removed by coagulation, sedimentation and filtration. High observed turbidity value may not pose an insurmountable problem since the water will still undergo serial treatments. High TSS mean values at these stations greater than $30.0 \mathrm{mg} / \mathrm{L}$.

FEPA (1991) limit can also be tackled through the processes that removes turbidity. Iron is not a toxic parameter; rather the guideline is based on aesthetic characteristics. WHO (2008) had suggested a concentration value of $0.30 \mathrm{mg} / \mathrm{L}$ because above this concentration, it stains laundry and plumbing fixtures. It could also increase water turbidity and colors. Iron could be removed by coagulation and ion-exchange mechanism. Since the water from these stations is raw and will undergo treatment, the presence of coliform is not a threat, but, just an indication of feacal contaminant (Taiwo, 2010).

A very high TDS observed at Lekki station higher than WHO standards is an indication of pollution from inorganic salts and organic substances dissolved in water (ANZECC, 2000). Significant $(\mathrm{p}<0.05)$ value of TDS at this station may be connected to intrusion from Atlantic Ocean tidal waves which is not far from the 
site (Martins and Awokola, 1996; Ahonkhai and Chukwuogo, 1996). Jaji et al. (2007) recorded high values of TDS in Ogun River at site close to Lagos Lagoon. Further confirmation of ocean intrusion for high value of TDS at Lekki station was found in the significantly high values of EC and chloride. Awomeso et al. (2010) in a related work conducted on a stream in Lagos found TDS and EC values in the range 673-45216 $\mathrm{mg} / \mathrm{L}$ and $1.5-43 \mathrm{mS} / \mathrm{cm}$ respectively.

Elevated values of solids are indications of the presence of array of chemical and non-chemical contaminants. According to WHO, TDS above $1000 \mathrm{mg} / \mathrm{L}$ would increase the unpalatability of water and may be objectionable to consumers due to excessive scaling in pipes, heaters, boilers and household appliances. High value of chloride and conductivity in water may also indicate indiscriminate disposal of raw wastes and sewage into a water body (Taiwo et al., 2010).

High concentration of chloride, EC and TDS at Lekki station could be a major problem to water abstraction and subsequent treatment. It is a clear indication of saline water. Salinity in water could be expensive to remove. The effective way of removal is by reverse osmosis. Reverse osmotic plant is very costly and could be hardly afforded by any developing nation. At the upper course of the River at Osun state, which is about $300 \mathrm{~km}$ from the first sampling point in this study, Olajire and Imeokparia (2001) reported high values of EC, nitrate and chloride. However, the TDS and chloride values obtained from Lekki sampling station remained the highest compared to previously reported values by Olajire and Imeokparia (2001) and relative to the other sampling stations.

Significant higher sulphate and faecal coliform values at Lekki sampling station may be attributed to direct wastes disposal from septic effluent and animal wastes, as well as run off of faecal contaminants from non-point sources (Fatoki et al., 2001; Jaji et al., 2007; Taiwo,
2010). Chromium was also detected at this site (Lekki) while it was not detected at the other two sites (Ogbere and Igbonla). What this portrayed is that this site is heavily polluted. High measured parameters at Lekki could not be unconnected with industrial discharges from Lagos metropolis into the Lagos Lagoon. High significance $(\mathrm{p}<0.05)$ concentration of COD at Lekki station could be linked to industrial waste discharges with the presence of biologically resistant organic matters (Sawyer and McCarty, 1978). Previous work of Awomeso et al. (2010) has shown high COD values in a stream polluted by textile industry in Lagos. Other environmental risks associated with surface water abstraction include changes in water flow, impingement of small fish leading to sharp reduction in juvenile population, and entrainment of planktonic organisms (Bamber and Seaby, 2003, Maes et al., 2004). Also, abstraction of water for electricity could lead to thermal pollution. Since cooling water is returned into the water body at a high temperature.

As this study is concerned, our priority is water quality. This has been observed and the results extensively discussed. In line with the study results, abstraction of raw water from Osun River at Ogbere and Igbonla for conventional treatment waterworks to satisfy Lagos and Ogun state water requirement is safe and economical. The quantity of water in River Osun at Lekki is very high, but cannot be utilized for drinking purposes due to outrageous cost of treating the saline water. Water can be abstracted from the river at Ogbere and Igbonla axes at reasonable treatment costs.

\section{CONCLUSION AND RECOMMENDA- TION}

The study has revealed variations in water quality parameters at the three sampling locations. Water quality parameters were generally low at Ogbere and Igbonla axes of Osun River compared to Lekki station. Abstraction of water from these two locations for treatment will be less costly and sustainable while at Lekki station, the cost will be very high due to high 
chloride and EC concentrations. This study thereby, recommends to various governmental arms especially the Federal Government of possible and cost-effective establishment of water treatment plant at Ogbere and Igbonla axes of Osun River. This will reduce the persistent water-shortage problems being experienced by the residents of both Lagos and Ogun states. Adequate supplies of potable water are prerequisite to good standard of living. This paper therefore, calls for immediate action by the government for sustainable supply of potable water for her citizens; so that WHO goals of access to clean water could be achieved.

\section{ACKNOWLEDGEMENTS}

Authors acknowledged the contributions of the technologists from Department of Environmental Management and Toxicology (Mrs. Sorinola A. O. and Mr. Olopade, E. A.), and Department of Water Resources and Agrometeorology (Mr. Abhulimen, S. I. and Mrs. Fasina, A. O.) during the laboratory analyses.

\section{REFERENCES}

Adeleke, M. A., Sam-Wobo, S. O., Mafiana, C. F. and Olatunde, G. O. (2011). Perception on bioecology of onchocerciasis vectors around Osun River, South-western Nigeria, J. Pub. Health Epi-demiol. 3(4): 162-166.

Adeleke, M. A., Mafiana, C. F., Sam-Wobo, S. O., Olatunde, G. O., Ekpo, U. F., Akinwale, O. P. and Toe, L. (2010). Biting behaviour of Simulium damnosum complex and Onchocerca volvulus infection along the Osun River, Southwest Nigeria. Parasites \& Vectors 3:93. http:// www.parasitesand vectors.com/ content/3/1/93.

Ademoroti, C. M. O. (1996). Standard methods for water and effluents analysis. Foludex Press Ltd., Ibadan. Pp.32-118

Ahonkhai, S. I. and Chukwuogo, E. I. (1996). Effects of industrial activities in Warri area on the surface water quality. Environ.
Monit. Assess. 16: 259-264.

ANZECC (Australian and New Zealand Environment and Conservation Council) (2000). Water quality Guidelines. http:// www.mfe.govt.nz/publicatios/water/anzecc -water-quality-guide-02

APHA (1998). Standard Methods for the Examination of Water and Wastewater. $17^{\text {th }}$ Edn., APHA-AWWA-WPCF 1998. Washington D.C

Awomeso, J. A., Taiwo, A. M., Gbadebo, A. M. and Adenowo, J.A. (2010). Studies on the pollution of waterbody by textile industry effluents in Lagos, Nigeria. $J$. Applied Sci. Environ. Sanitat. 5:353-359.

Bamber, R. N. and Turnpenny, A. W. H. (1986). Trial of a Johnson 715 alloy wedge -wire screen at an UK coastal site. Re-port No. TPRD/L/3012/R86, Central Electricity Research Laboratories, CEGB, London.

Correll, D. and Naeve, H. (1998). The role of phosphorus and eutrophication of receiving waters. A Review. J. Environ. Qual. 27: 261-266.

D'Amelio, S. (2007). Preliminary water quality at Springbank Dam, Thames river, London, Ontario.Trout Unlimited $\mathrm{C}$ a $\mathrm{n}$ a d a Technical report No. ON-020. p. 7-11.

DEFRA (2011). Abstraction from non-tidal surface water and groundwater by use: 1971-2007. Department for Environment, Food and Rural Affairs. http://achive. Defra.gov.uk/evidence/statistic/environment/ inlwater/kf/iwkfiz.htm. Accessed:17/07/11.

Einum, S., Henry, A. and Fleming, I. (2002). Egg-size evolution in aquatic environments: Does oxygen availability constraint size? Proceedings of the Royal society of London 269: 2325-2330 
Fatoki, O. S., Muyiwa, N. Y. O. and Lujiza, N. (2001). National water supply and sanitation policy ( $1^{\text {st }}$ edn.). Federal Ministry of Water Resources, Abuja, Nigeria.

FEPA (1991). Water Quality, Federal Water Standards, Guidelines and Standard for Environmental Pollution Control in Nigeria. National Environmental Standards-Part 2 and 3, Government Press, Lagos, pp: 238

Gbadebo, A. M., Oyedepo, J. A. and Taiwo, A . M. (2010). Variability of nitrate in groundwater in some parts of southwestern Nigeria. Pacific J. Sci. Technol., 11: 572-584.

Jaji, M. O., Bamgbose, O., Odukoya, O. O. and Arowolo, T. A. (2007). Water quality assessment of Ogun river, South West Nigeria. Environ. Monit. Assess. 133: 473-482.

Longe, E. O., Malomo, S. and Olorunniwo, M. A. (1987). Hydrogeology of Lagos metropolis. J. Afri. Earth Sci. 6: 163-174.

Maes, J., Turnpenny, A. W. H., Lambert, D., Nedwell, J. R., Parmentier, A. and Ollevier, F. (2004). Field evaluation of a sound system to reduce estuarine fish intake rates at a power plant cooling water inlet (Doel, Belgium). J. Fish Biol. 64: 938-946.

Martins, O. and Awokola, O. S. (1996). Total dissolved solids of selected rivers in SouthWestern Nigeria. J. Mining Geol. 32 (2): 113-119.

Miettinen, I. T., Vartiainen, T. and Martkainen, P. J. (1997). Phosphorus and Bacterial Growth in Drinking Water. Applied Environ. Microbiol. 63 (8): 3242-3245.

Olajire, A. A. and F. E. Imeokparia (2001). Wa -ter quality assessment of Osun River:Studies on inorganic nutrients. Environ. Monit. Assess. 69: 17-28.
Olorunfemi, M. O. (2004). Subsurface sequence delineation and saline water mapping of Lagos State, Southwestern Nigeria. Global J. Geological Sci. 2: 111-123.

OORBDA (1982). Ogun-Osun River Basin Development Authority. Feasibility Study, Volume 7.

Orebiyi, E. O., Awomeso, J. A., Martins, O., Idowu, A. O., Oguntoke, O. and Taiwo, A. M. (2010). Assessment of pollution hazards of shallow well water in abeokuta and environs. Am. J. Environ. Sci. 6: 50-56.

Sawyer, C. C. and McCarty, P. L. (1978) . Chemistry for Environmental Engineers. McGraw Hill, New York, pp331-514.

Taiwo, A. M. (2010). Environmental impact of poultry farm operations on Alakata stream at Isolu in Abeokuta, Nigeria. Master Thesis, Department of Environmental Management and Toxicology, University of Agriculture, Abeokuta.

Taiwo, A. M. (2011). Composting as a sustainable waste management technique in developing countries. Journal of Environ. Sci. Technol. 4 (2): 93-102.

Taiwo, A. M., Gbadebo, A. M. and Awomeso, J. A. (2010). Potability assessment of selected brands of bottled water in Abeokuta, Nigeria. J. Applied Sci. Environ. Manage. 14:47- 52.

Turnpenny, A. W. H. and Coughlan, J. (2003). Using Water Well: Studies of Power Stations and the Aquatic Environment. Innogy plc, Swindon, UK, 142 pp.

WHO (2006). Guidelines for drinking water quality. Second Addendum to third Edition Volume 1 recommendation. WHO, Geneva. 
67 Awomeso et al.

WHO (2008). Guidelines for Drinking Water porting Information, WHO, Geneva, 668p. Quality. 3rd Edn., Health Criteria and Sup- 